\title{
BRINGING WORLD CINEMA INTO THE HISTORY CURRICULUM
}

\author{
Ronald Briley \\ Sandia Preparatory School, Albuquerque, NM
}

Imagine a flyer promoting a history elective prominently featuring the image of a black-robed Death figure with the following caption: "If you would like to screen a two-hour black and white film in Swedish with English subtitles in which a knight plays chess with death while discussing the meaning of life and such philosophical questions as the existence of God, then this is the class for you." It was with some trepidation that I tried this novel approach for recruitment into a new history elective five years ago. And it worked, perhaps offering a certain snob appeal for some students. But I prefer to believe that "Introduction to World Cinema" addressed student intellectual curiosity regarding film and filmmaking as well as learning more about other cultures in our ever-shrinking world.

Over twenty-five years ago, I encountered resistance to a proposed class in which Hollywood feature films would be employed as primary sources through which to investigate the formation of American values and ideology in the post-World War II period. In other words, these films would be examined to ascertain how they reflected the time periods in which they were made. ${ }^{I}$ Thus, I would not use High Noon (1952) to examine the American West. Instead, High Noon offers insight into such essential issues and concerns of the 1950s as the Cold War, communism and anticommunism, the Hollywood Ten, conformity, and suburbia. In a similar fashion, Bonnie and Clyde (1967) tells us more about the 1960s than the Depression era in which the film was set. A careful analysis of such films, supplemented by the well written and researched history of post-World War II America provided by William Chafe in The Unfinished Journey, has today made "U.S. History through Film" a respected part of the history curriculum at Sandia Preparatory School. ${ }^{2}$ Having an established place for film history in the curriculum made it easier to find acceptance of "Introduction to World Cinema" by various school constituencies of administrators, teachers, parents, and students.

Recent historiographical and pedagogical trends to better place the American experience within the context of global history convinced me that the approach of the

\footnotetext{
${ }^{1}$ Ron Briley, "U.S. History, 1932-1972. As Viewed through the Lens of Hollywood," The History Teacher 23 (May 1990), 215-236.

${ }^{2}$ William Chafe, The Unfinished Journey: America Since World War II (New York: Oxford University Press, 2010).
} 
U.S. film class was a bit narrow. ${ }^{3}$ While Hollywood continues to exert considerable influence upon international filmmaking, a purely American approach to the study of film ignores major contributions to the art of cinema in Europe, Latin America, Asia, the Middle East, and Africa.

Accordingly, the "Introduction to World Cinema" class offers an opportunity to break down cultural and national boundaries, as well as challenge ethnic and racial stereotypes, through the medium of film-perhaps the most important art form of the twentieth and twenty-first centuries. This cinematic approach to world history allows students to examine the human condition through the lens of nationality, history, genre, and the artistic contribution of individual filmmakers. As with the American history film course, I expect students to place the international film texts within the historical and cultural contexts in which they were produced. Thus, a cinematic perspective provides an opportunity for upper-level students to apply their knowledge of world history from survey courses taken in their first two class years. But rather than simply a global history through film, the class is also a survey of World Cinema with representative artists and films from various historical and cultural traditions. To study the art of film properly, students must be exposed to film form or the grammar and language of film. An excellent source for understanding better how to analyze cinema is Film Art by David Bordwell and Kristin Thompson, a book that also might be valuable for filmmaking classes and is employed throughout the Introduction to World Cinema course. ${ }^{4}$

Of course, in one class it will be impossible to address equally the broad spectrum of cultures represented by world cinema, so the films I have chosen for screening in class by necessity will be somewhat selective. The key is to provide examples of the diverse offerings provided by essential global fiilmmakers and to encourage students to explore further on their own time the rich possibilities of international film. Texts such as the Oxford History of World Cinema by Geoffrey Nowell-Smith and $A$ Short History of Film by Wheeler Winston Dixon and Gwendolyn Audrey Fowler will aid teachers in the selection of appropriate films for a world cinema course. The Dixon/Fowler text, organized chronologically, is certainly accessible for senior-level high school students, and I use it throughout the course. ${ }^{5}$ Deciding which films to employ in class is really one of the most fun things to do in preparation for the

${ }^{3}$ Carl Guarneri, America in the World: United States History in a Global Context (New York: McGrawHill, 2007); Michael Schaller, Robert Schulzinger, et al., American Horizons: U.S. History in a Global Context (New York: Oxford University Press, 2012).

${ }^{4}$ David Bordwell and Kristen Thompson, Film Art: An Introduction (New York: McGraw-Hill, 2010).

${ }^{5}$ Wheeler Winston Dixon and Gwendolyn Audrey Foster, A Short History of Film (New Brunswick, NJ: Rutgers University Press, 2009); Geoffrey Nowell-Smith, ed., The Oxford History of World Cinema (New York: Oxford University Press, 1997). 
course and makes one feel as if he or she is preparing a film festival or operating one's own art house cinema. Accordingly, the following summary of films that I have used in the class includes footnotes with additional reading recommendations on the film texts. While the readings might also be assigned to students, the primary purpose of the notes is to guide teachers to more in-depth readings on the films and filmmakers.

Of course, evaluation of student performance is always a major issue for teaching, and I use several evaluative tools for the class. To make sure that students are keeping up with course readings, I will sometimes give quizzes. Students also have the opportunity to prepare oral presentations on films and filmmakers that we do not have time to show in class-including some more contemporary examples of world cinema. The bulk of our class time is occupied with discussion of the screened film texts. I usually begin discussion with a general question as to whether students found the film interesting, and from there we move onto more analytical concerns as to what the film tells us about the filmmaker, the culture, and the historical context in which the cinematic work of art was produced. We follow these discussions with analytical writing assignments in which students expand upon the themes raised by classroom discourse. The following discussion of film texts employed in the course will include representative examples of the type of essay questions to which students are expected to respond. While the World Cinema class is a history course with an emphasis upon feature films as historical artifacts or primary sources, we also have a filmmaking class at the school, and some of the World Cinema students also enroll in the more creative filmmaking course and are encouraged to share their activities, screenplays, and short films with classmates in World Cinema.

Therefore, let me share some thoughts on films that I have included in the World Cinema class. I begin with three silent films. Similar to the experience with subtitles and viewing black and white films, if one expects students to treat film as an art form worthy of serious study, they usually have little problem adjusting to the differing visual style of silent film which is also made easier by the musical soundtracks that accompany silent features on contemporary DVD reproductions. For the silent unit of the class, I use Sergei Eisenstein's Battleship Potemkin (1925), Charlie Chaplin's The Gold Rush (1925), and Fritz Lang's Metropolis (1926). Eisenstein's film celebrating the Bolshevik Revolution and the role played by the vanguard of the proletariat might not be popular with contemporary students, but his work certainly demonstrates the propaganda possibilities of film. Chaplin's Gold Rush, using the Klondike gold strike of the 1890 s to comment upon the shallow commercial culture of the 1920 s, is a favorite of students, offering an opportunity to analyze and appreciate Chaplin's approach to humor and social commentary that enjoyed international popularity and acclaim. Lang's Metropolis introduces students to the artistry of German Expressionism, and the political ideas suggested by the film provide a forum for discussing the rise of Hitler and the Nazi Party in Germany as exploited workers seek a mediator to alleviate their condition. And the visuals are simply stunning, with students often amazed that Lang was able to produce such images without the aid of 
of reality, is set in the swinging London of the 1960s and challenges students who are, nevertheless, captivated by the film's cinematography, use of color, and philosophical implications. ${ }^{10}$ The essay assignment for the auteur unit requires students to pick one of the directors and discuss how their work is distinctive.

Although existing apart from the European mainstream, the Soviet filmindustry, building upon the legacy of Eisenstein, played an influential role in world cinema. The centrality of the Second World War to Russian history and culture is evident in such films as Andrei Tarkovsky's Ivan's Childhood (1962) and Mikhail Kalatozov's The Cranes Are Flying (1957). Students are especially drawn to the tragic love story between Boris and Veronika in The Cranes Are Flying as well as the film's message of peaceful coexistence during the Soviet cultural "thaw" following the death of Joseph Stalin. Similar themes of how Americans and Russians are not really so different are apparent in Vladimir Menshov's Moscow Does Not Believe in Tears (1979), a film that played well in the United States and was a favorite of Ronald Reagan. ${ }^{11} \mathrm{I}$ ask students to write about what these film texts reveal about life in the Soviet Union during the second half of the twentieth century.

The influence of Eisenstein is also manifested in the political cinema of the 1960 s, which challenged the political hegemony of the United States and Western Europe as well as the Soviet Empire. The political thriller $Z$ (1969), directed by Constantine Costa-Gavras, denounced the military dictatorship in Greece and its support by the United States. The political milieu of the post-World War II decolonization and wars of national liberation is captured in the powerful Battle of Algiers (1965) directed by Italian filmmaker Gillo Pontecorvo. Funded by the revolutionary Algerian government and filmed in a documentary fashion employing techniques of neorealism, Battle of Algiers describes the struggle for Algerian independence from France. The film examines the efficacy of terrorism and torture, giving the film a contemporary feel while offering students an opportunity to discuss the foreign policy of the United States in Iraq and Afghanistan. ${ }^{12}$

The themes of decolonization and independence provide a bridge to the study of film in Asia, Latin America, Africa, and the Middle East. The Japanese film industry

\footnotetext{
${ }^{10}$ Federico Fellini, Fellini on Fellini (New York: Da Capa Press, 1996); Ingmar Bergman and Joan Tate, The Magic Lantern: An Autobiography (Chicago: University of Chicago Press, 2007); Peter Brunett, The Films of Michelangelo Antonioni (Cambridge, UK: Cambridge University Press, 2012).

${ }^{11}$ Jay Leyda, Kino: A History of the Russian and Soviet Film (Princeton: Princeton University Press, 1983); Birgit Beumers, A History of Russian Cinema (New York: Bloomsbury Academic, 2009); Tony Shaw and Denise Youngblood, Cinematic Cold War: The American and Soviet Struggle for Hearts and Minds (Lawrence: University Press of Kansas, 2010).
}

${ }^{12}$ Carlo Celli, Gillo Pontecorvo: From Resistance to Terrorism (Secaucus, NJ: Scarecrow Press, 2005); John J. Michalyczyk, Costa-Gavras: The Political Fiction Film (Philadelphia: Art Alliance Press, 1984). 
is one of the most significant in global cinema, and students in World Cinema must be exposed to one of the world's master filmmakers Akira Kurosawa, whose work has even influenced George Lucas and the Star Wars saga. Among the Kurosawa films that one might share with students are Rashomon (1950), Throne of Blood (1957), The Hidden Fortress (1958), Kagemusha (1980), and Ran (1985). However, I would recommend screening The Seven Samurai (1954), despite its nearly four-hour running time. In The Seven Samurai, Kurosawa employs the Samurai tradition to raise questions about the nature of post-World War II Japanese society following the end of the American occupation. Themes of social mobility, gender roles, social class, changing technology, honor, and tradition are explored in this masterpiece of the cinema. The ambiguity with which the Samurai, who saved a village from bandits, are treated relates well to the gunfighter in such American Westerns as Shane (1952), once again allowing students to place American history and culture in a more global framework. Although lacking the action of Kurosawa's epic, Yasujiro Ozu's Tokyo Story (1953) also examines Japan's postwar culture. Ozu tells the story of grandparents who travel from the countryside to visit their children and grandchildren in the bustling environment of contemporary Tokyo. The children and grandchildren, however, have little time for aging relatives, and the trip ends tragically. Ozu's simple but powerful tale interrogates the changing nature of Japanese culture, but the film also resonates with students for its universal themes regarding family. This film is an important humanizing portrayal of the Japanese people that played well in American art houses only eight years after the brutal war in the Pacific and the unleashing of atomic bombs on Hiroshima and Nagasaki. ${ }^{13}$

While viewers in the United States could view Japanese films easily, the politics of the Cold War limited access for Americans to Chinese cinema until the 1970s when Chinese films assumed a larger role on the world stage. Themes of contemporary life in China addressed through historical period films are the staple of acclaimed Chinese director Yimou Zhang whose work has enjoyed distribution in the United States. I have found his Raise the Red Lantern (1991), featuring Gong Li, to be quite effective in raising questions regarding the state of Chinese politics and economic development. The film is set in the early twentieth century before the Chinese Revolution and may be read as a condemnation of the exploitation of women and the working class by the elusive capitalist Master in this beautifully photographed film. An alternative and more allegorical interpretation of Raise the Red Lantern perceives the Master as a representation of the Communist Party. The mistresses of the Master are allowed to enjoy a fairly affluent lifestyle, but there is no toleration for dissent or disobedience.

\footnotetext{
${ }^{13}$ Alistair Phillips and Julian Stringer, Japanese Cinema: Texts and Contexts (London: Routledge, 2007); Stephen Prince, Warrior Cinema: The Cinema of Akira Kurosawa (Princeton: Princeton University Press, 1999); Donald Richie, The Films of Akira Kurosawa (Berkeley: University of California Press, 1999).
} 
When the Third Mistress defies the Master, she is murdered in a scene reminiscent of the brutality inflicted upon protesters in the 1989 . Tiananmen Square Massacre. ${ }^{14}$

In addition to Japanese and Chinese cinema, we also examine the influence of India and its film capital Bollywood upon international film. While many excellent Bollywood films might be used in the classroom, I would recommend Lagaan (2001), which involves a challenge cricket match between Indians and their British masters before independence. This film contains the usual elements of Bollywood, such as interrupting the narrative for a musical number, but Lagaan also provides an opportunity for students to examine the resistance of Indians to British imperialism by employing the English game of cricket as a means through which to avoid the imposition of a land tax-in other words, hoisting the colonizers on their own petard. Another powerful film for the classroom is Earth (1998), directed by Deepa Mehta, a Canadian product of the Indian diaspora. Earth, part of a controversial trilogy of films dealing with life in India directed by Mehta, is concerned with the partition of India following independence and focuses upon how religious differences are manipulated to divide former friends. The beautiful Hindu, Shanta (Nandita Das), is pursued by two Muslim suitors, Dil Navaz (Aamir Khan) and Hassan (Rahal Khanna), and the end result of this love triangle is a brutal and unsettling conclusion that parallels the violence accompanying the partition of the Indian subcontinent into India and Pakistan. In addition to the platform that this film presents for students to consider the continuing confrontation between Hindus and Muslims in the region, the treatment of Shanta also provides students a framework through which to discuss the violence against women that seems to plague contemporary India. ${ }^{15}$

Latin America also has a rich cinematic heritage, but I must confess that my World Cinema class curriculum is somewhat limited on this topic as most of our upperdivision students take Spanish, and one of our teachers focuses upon Latin American film. However, I would like to share some brief comments on four recent films that I have found to be effective in the World Cinema classroom. The rich tradition of Magical Realism in Latin America, exemplified by the literature of Gabriel Garcia Márquez, is well illustrated in Mexican filmmaker Guillermo de Toro's Pan's Labyrinth (2006), set during the Spanish Civil War. This story of the brutality and evil found within fascism and the efforts of an innocent young girl to escape and find refuge

\footnotetext{
${ }^{14}$ Christopher J. Berry and Mary Ann Fargahar, China on Screen: China and Nation (New York: Columbia University Press, 2006); Yingjin Zhang, Chinese National Cinema (London: Routledge, 2004); Francis Gatewood, ed., Zhang Yimou: Interviews (Jackson: University Press of Mississippi, 2001).
}

${ }^{15}$ Vijay Mishera, Bollywood Cinema: Temples of Desire (London: Routledge, 2001); Bhaskar Sarkar, Mourning the Nation: Indian Cinema in the Wake of Partition (Durham: Duke University Press, 2009); Devyani Saltzman and Deepa Mehta, Shooting Water: A Memoir of Second Chances, Family, and Filmmaking (New York: William Morrow, 2007). 
in a fantasy world is certainly popular with students. A more realistic examination of resistance to the history of military dictatorship in Latin America, often supported by the United States, can be found in The Official Story (1995). The film focuses upon the protests of women in Argentina seeking information regarding family members who disappeared during the military dictatorship of the 1970s. History teacher Alicia Marnet de Ibáñez (Norma Alandro) comes to recognize that her adopted daughter and affluent lifestyle are dependent upon the compromises her husband Roberto has made with the corrupt military government. When writing upon The Official Story, students are asked to interrogate the nature of official truths presented by governments and the obligation of citizens to challenge such official stories. In No (2013), Gael Garcia Bernal plays a young advertising executive who employs the techniques of modern American advertising to win a 1988 plebiscite that drove Chilean dictator General Augusto Pinochet from power. The irony of using American popular culture to depose an autocrat who seized power in a coup backed by the United States raises a number of questions and ambiguities that students find fascinating. But for most students, their favorite film in the course is the Brazilian picture City of God (2002), directed by Fernando Meirelles. City of God, which enjoyed a popular run in American theaters, focuses upon the favelas created by the Brazilian military dictatorship of the 1960s. While the government initially promoted the favelas as a program to address poverty, the reality has proven to be the creation of slums in which crime and corruption abound far from the upper and middle-class neighborhoods of Rio de Janeiro. In an artistic tour de force, Meirelles depicts the culture of violence, drug dealing, and official corruption that makes it almost impossible to escape the favelas. While most students love this film, I try to challenge this assumption by presenting them with reviews that question whether the film's bright colors and glitzy production values rather than a grittier look tend to glamorize violence. With these reviews, I try to raise the question of whether Meirelles avoids social responsibility by offering no solution to the problems of the favelas. And with the World Cup and 2016 Olympics just past, the favelas are certainly on the world's radar screen. ${ }^{16}$

A fair criticism of the World Cinema class is that we do not do enough with the films of the Middle East and Sub-Saharan Africa. There are strong film industries in Egypt, Palestine, and Istael, but due to time limitations I generally focus upon Iranian cinema which well reflects the complexity of a nation that many Americans struggle to understand. The diversity of Iranian culture is most evident in filmmaker Ashgar Farhadi's $A$ Separation (2011), which was the first Iranian film to win an Academy Award for Best Foreign Language Picture. The religious, class, gender, and

\footnotetext{
${ }^{16}$ Aberto Elena, Marina Diaz Lopez, and Walter Salles, The Cinema of Latin America (New York: Wallflower Press, 2004); John King, Magical Reels: A History of Cinema in Latin America (New York: Verso, 2000); Deborah Shaw, Contenporary Latin American Cinema: Breaking into the Global Market (New York: Rowman \& Littlefield Publishers, 2007); Mar Diestro-Dopido, Pan's Labyrinth (London: British Film Institute, 2013.)
} 
generational differences that characterize contemporary Iran are on display in this film as an educated middle-class family procures a poor woman from a more fundamentalist religious family to care for an aging male parent. A legal dispute arises over this care, allowing students a glimpse into the diversity of contemporary Iran. The divorce proceedings between Simin and her husband Nader, who refuses to leave Iran and his ailing father, also challenge student stereotypes of women in Iran and the Middle East. Preconceived assumptions about Iran are also interrogated in Bahman Ghobadi's No One Knows about Persian Cats (2009). This film, which includes documentary footage as well as a fictionalized story line, concerns the efforts of young Iranian musicians to gain visas that would allow them to perform in Europe. Employing music videos from the Iranian rock music scene, Persian Cats demonstrates that there is an active underground alternative music scene in Teheran despite the endeavors of the conservative government to place strict regulations over cultural expression. Through much of the film there is a lighter mood of poking fun at the authorities, but Persian Cats concludes with tragedy that often leaves students stunned. In response to the film, the Iranian government no longer allows Ghobadi to work in the country, and ironically some of the musicians featured in the film were able to relocate to New York City where several were killed in a shooting growing out of a personal rather than political dispute. Students who love music are drawn to this film, which demonstrates that despite the political and diplomatic differences between the United States and Iran, young people in the two nations share common elements of music culture exemplified through the power of world cinema. ${ }^{17}$ For the essay assignment on this unit, I ask students to employ the films as windows into issues of gender, class, and justice within contemporary Iran.

Our World Cinema class does not do enough with the growing film communities of Sub-Saharan Africa, especially Nigeria, whose film industry, known as Nollywood, is second only to India's Bollywood in the number of features released annually - although many of these features are not readily available in the West for classroom use. However, this is beginning to change, and I have employed such African features as One God, One Nation (Nigeria, 2005) and Nairobi Half Life (Kenya, 2012). Students in World Cinema must also be introduced to the pioneering work of Senegalese director Ousmane Sembène, considered to be one of the first and perhaps still the best of African filmmakers. Condernnation of French political and cultural imperialism is well developed in Sembène's Black Girl (1966). The film tells the story of a young African woman whose employers take her to Paris where she works as a domestic. Isolated from her culture, the young woman tries to find solace in a

\footnotetext{
${ }^{17}$ Hamid Reza Sadr, Iranian Cinema: A Political History (New Yotk: I.B. Tauris, 2006); Hamid Naficy, A Social History of Iranian Cinema, Volume 4: The Globalizing Era, 1984-2010 (Durham: Duke University Press, 2012); Hamid Dabashi, Close Up: Iranian Cinema, Past and Future (New York: Verso, 2001).
} 
mask that reconnects her with African culture. The film ends tragically and is often upsetting to students, but Ousmane sends a powerful anti-imperialist message. ${ }^{18}$.

This survey of films that I have employed in the World Cinema class is hardly an exhaustive list, but it does suggest the diverse possibilities of using film to investigate global history and culture. In focusing upon some of the key filmmakers who first influenced world cinema, my selection of films is rather Eurocentric, but in the last two years $I$ have tried to expand the range of films to which students are exposed in order to promote greater cultural understanding. But no matter what films are chosen for screening — and I would suggest including students in this process - time is always a limiting factor in the classroom. I am fortunate to have two one-hour class periods per week which are adequate for screening most of the films, with three fortyfive minute blocs for discussion and class presentations. Thus, my goal is to screen a film per week if there are not too many interruptions with the schedule. Of course, I could gain additional class time by having students screen the films at home, but I would argue that there is much to be gained by gauging student reaction in a community viewing. In addition, I sometimes make comments during the screenings to clarify a historical or cultural point about which students might be unfamiliar. Although I believe that complete viewings of the films are best, teachers who wish to utilize world cinema to supplement world history courses might include carefully selected film clips whose context must be developed and explained. I should note that some of the films might include scenes that parents find objectionable. Accordingly, I would suggest that parents sign a permission form for the class in which they are apprised of all films to be viewed in the class. Teaching a senior elective for seventeen and eighteen year-old students on the eve of college, I have not found film content to be a major problem with the class.

In conclusion, the World Cinema course has presented an excellent opportunity to broaden student horizons regarding film and world history by examining this art form within historical and cultural contexts. It is, indeed, the class for you if you would like to pursue some of the essential questions posed by Bergman in The Seventh Seal. And it is not simply a class that only appeals to students of the humanities: I have been humbled by comments of former students at the university majoring in math and science who assert that the World Cinema class altered their perception of both film and history. The class requires a great deal of labor on the part of both teachers and students, but for those willing to tackle the challenges of world cinema, the reward should be a deeper understanding of the diverse and complex world in which we reside as global citizens.

\footnotetext{
${ }^{18}$ Annett Busch and Max Annas, eds., Ousmane Sembène: Interviews (Jackson: University of Mississippi Press, 2008); Kenneth W. Harrow, Postcolonial African Cinema: From Political Engagement to Postmodernism (Bloomington: Indiana University Press, 2007); Mahit Saul and Ralph A. Austen, Viewing African Cinema in the Twenty-First Century Art Film and the Nollywood Video Revolution (Athens: Ohio University Press, 2010); David Murphy and Patrick Williams, Postcolonial African Cinema: Ten Directors (Manchester: Manchester University Press, 2008).
} 